\section{研究会記 録}

日時：昭和 32 年 4 月 15,16 日 場所：静岡県伊東市光風閣

\section{研究会次第}

(1) 澱粉製造関係

1. 磨砕ロールの大きさ, 目立, 回転数等

2. 分離機 3. 沈澱池, テーブリング

4. 遠心分離 5. 乾燥 6 . 二番粉の回収

7. 石灰法 8. 澱粉の品質

（2）澱粉の精製について

（3）水飴・ぶどう糖関係
1. 糖化工程
2. 沪過工程
3. 脱色工程
4. 仕上工程
5. イオン交換について
6. 麦芽飴
7. 細菌アミラーゼ

（4）化工澱粉その他

（5）小麦測粉その他

(6) 経営関係

\section{技術研究会 議事録（要旨）}

\section{〔第 1 日]}

(1) 開会の挨拟

鈴木常任理事

(2) 挨 拶 木原理事長

（3）会の進行につき鈴木常任理事より説明 今回はシンポジゥム型式で進めるが座長には特 に地方の技術者になつてもらう。

(4) 技術研究会

\section{海粉製造関係中 沈澱池まて（座長 後藤富士雄氏）}

座長：先ず原料いも関係で何かあつたらお願いしたい。 二国：大阪大学に近くコバルト 60 が入るが，これを 使つて貯蔵関係の研究を行う予定である。馬鈴 薯についての研究では貯蔵性が良くなることが わかつているが, 甘藷の場合, 貯蔵の問題が解 決されるならば，澱粉工場の操業を長くするこ とが出来るのかどうか？

座長：或程度峙可能であると思う。これについて長崎 の島田さん何かあつたら。

島田：従来の貯蔵方法による場合は成分変化が起る。 これに関連して一つの方法として早熟種を栽培 することも考えられる。現在は農家に上手に貯 蔵させる方法をとつている。放射線を使つてい もに休眠状態を与えることは非常に有効である と思う。

鈴木(繁)：現在甘藷に使えるかどうかを農研, 食研で
検討中である。耐寒性の機構がまだ判明しない ので,特に蔗糖と耐寒性が問題となる。又糖化, 橴の増加, 白度の低下等も問題となるだろう。 コバルト 60 を照射した場合,澱粉が変化するな らばこ和も問題となろう。甘諸の成分中, 渋と ポリフェノールが問題であるが, この場合食用, 原料用では区別して考える必要がある。農研で は現在 $r$ 線を使つて新品種の育成を行つている。 座長：大量を 1 ケ所に集めてやるのか, 又は農家で個 々にやるのか?

二国：大量でないとやれない。現在では基礎研究の段 階であるので, 来年の課題としたい。

山村：馬鈴薯の場合に呼吸変化はしていないのか?

二国：簡単な休眠状態である。

山村：11 月に大量処理出来れば非常に良いと思う。 鈴木(繁)：放射線による食品の保蔵に関しては, 食研の 吉川技官が抄録を出しているので連絡されたい。 本坊：甘藷の磨砕にハンマークラッシャーを国内で使 つているかどうかを聞きたい。

座長：これは専門の大野氏がまだ来ていないので，大 野氏がくるまで保留とする。

福岡：入荷原料と関連するが，堀取時期によつて澱粉 の粘度がちがうことがわかつた。早堀（9月上 旬）と晚堀（11月中旬）の澱粉のアミログラム は大体次のようであつた。

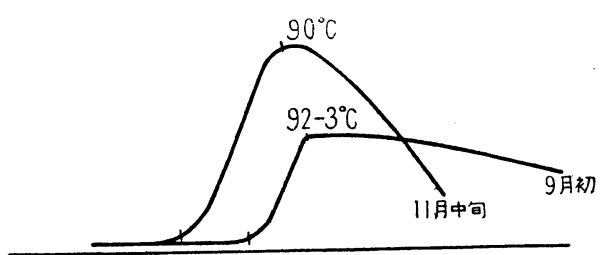

即ち糊化開始温度と最高粘度がちがつているが, これは粒子の大小の関係ではないかと思う。工 業原料用の澱粉としては粘度のコントロールが 必要。

鈴木(繁)：関連して生育中の各時期の澱粉のアミログ ラムについて説明。(詳細は省略)。本年度農芸 化学大会で発表した。澱粉の性質が生育時期に よつてある程度ちがう。又北海道の馬澱の 1 ,

2,3 等についてアミログラフイーを行つてみ たが，各等級間に差があつた。1 番粉と 2 番粉 （大粒子と小粒子）を比較すると粘度に差があ る。これは粒子の大小の相違と 2 番粉は不純物 
の関係があると思われる。ここで細菌アミラー ゼに関する研究(小巻氏)の概要を説明(詳細略) 澱粉粒を酵素液につけておくと粒の表面の軟か い部分がふかされミセルの再配列が起る。

又粘度変化は沈澱池や貯蔵の際の酵素作用によ るのではないかと思う。

福岡：粒経分布は測定しなかつた。顕微鏡写真は糊化 の際にはとつていない。

福場：小粒子が粘度が低いのは，粒の崩壊により，膨 潤に対する抵抗が強いからで法ないかと思う。 これは表面に膜があると考えられるか，二国先 生におたずねしたい。

二国：X線で水分と粒の大小の関係を研究している。 澱粉はだんだんと大きくなると思つている。 大きい粒程真中に水分が多い。即ち外側が強く 中側が弱い。大粒子程熱膨脹に対して抵抗が弱 く，内部からおかされてくる。

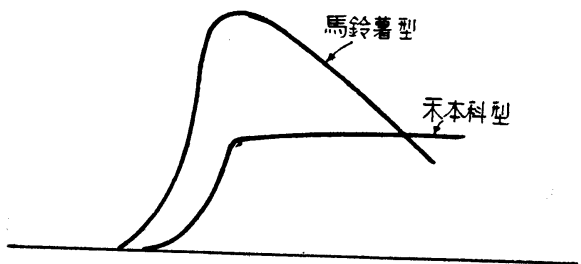

粒が一時に全部崩れ 次から次えと粒が崩 る系統 れてゆく系統

鈴木(繁)：馬澱にも二つの型がある。前述の 1 等と 2 等（1番粉と 2 番粉）の関係について説明。結 論は

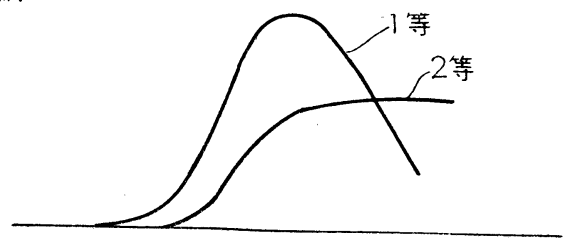

1 等……とわれ易い。大粒子が多い。

2 等……こわれ難い。小粒子が多い。

小巻：細菌アミラーゼを使つた場合， $83^{\circ} \mathrm{C}$ に加熱し て $100 \%$ 水溶性化するかどうか?

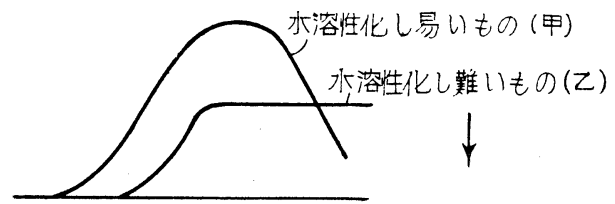

これをアミラーゼで部分消化すると，乙のカー ヴとなるのではないか。

甲から乙に変る方法は, 溶けるだけ溶けて, も ぬけの殼式の考え方で説明できないか。即ち残 りの溶け難いものは硬い筋が残つて表面にボッ ボツ穴があいて縮む。酵素の場合には甲の方が 良いと思う。

澱粉の色ゔきはポリフェノールと思われる。ア ミノ酸の銅活性酲で $\mathrm{pH} 4.0$ で銅が離れ，活 性を失い早くなる。 $\mathrm{pH} 3.0$ で色が白くなるそ うだが，その場合金属イオンの封鎮剤を使つた ら如何。

山村：ポリフェノールが銅化合物であることは判つて いる。 $\mathrm{pH} 4.0$ 以下にすると澱粉の色が白くな るが，あとの蛋白の除去が困難となる。オキシ ダーゼを働かせるとポリフェノールが少くな る。即ちポリフェノールの重合物を液中に出し て, 澱粉層に残つているポリフェノールを少く するわけである。摺込液の攪汼を多くすると酸 化が促進され，白くなる。ノズルゼット，エア ーコンプレッサー, 石灰法併用のものは効果が 多い(白度が高い)。

pH 7 以上にすると, 緑色となり，ポリフェノ ールとアミノ酸と結合した色であり，このよう に澱粉についたポリフェノールを引き出せば良 いわけである。このためにはオキシダーゼを働 かせれば良いと思う。エアレーションして上澄 が薄ければ薄い程澱粉は白い。尚品種によりポ リフェノールの含量が非常にちがうので, 原料 品種としてはこれの少ないものを選ぶことが必 要である。

又 1 昼夜放置した澱粉をエアレーションしても 白くならないのは，オキシダーゼが不活性化す るためと思う

二国：葛澱粉のオキシダーゼをチオウレアでやると良 かつた（色がつかなくなる）が，オキシダーゼ を(1)殺して白度に影響ないか？(2)或は殺さずに 働きかけた時との比較はどうか？

福場: (1)の場合は autoxidation が起る。

ポリフェノールの品種別含量はどうなつている のか?

山村：九州 18 号白センガン，農林 2 号, 農林 7 号は 非常に良い（ポリフェノール少い）。 源氏は一番悪い結果を示した。 
二国：澱粉粒の出来る初期には，アミロペクチンが多 く後期になる程アミロースが多いと思つていた が，鈴木氏の甘藷澱粉についての研究で法余り 変らないようだ。ミセルの配列状態が初期が強 く, 後期は弱いからではないかと思う。ところ で甘藷澱粉のアミログラフに対して，蛋白は影 響があるだろうか。

鈴木(繁)：蛋白の問題につき説明。蛋白の変性が澱粉 製造に大きく影響する。又これが，糊化の際の 粘度とどの様な関倸を持つかも問題である。 仕上節を通つた澱粉乳も水溶性蛋白の変性によ り影響を受ける。 $\mathrm{pH}$ が低い之澱粉内部にも蛋 白変性が起り,この点を考えねばならないと思 う。沈澱中の澱粉を時間毎に採り, 蛋白の变性 の影響をみれば良い。

福岡: コーンスターチでテーブリング終了後, 頭部と 末端のアミログラムをとつてみると，次図の様 である。甘藷澱粉でも同様に出てくる。 ( $\mathrm{pH}$ 6.3〜6.6 位)あまり $\mathrm{pH}$ と考光られない。

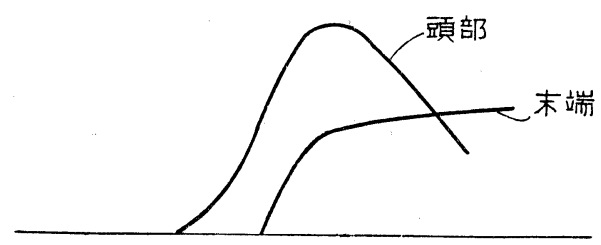

二国：それでは蛋白の影響も考虑に入れる必要もあろ う。然しこれ注分析にかかる程のものと思わ れない。

中村：こ机は干粉か生粉か？干粉ではカゼイネイト がないか？ 貯蔵期間の長短で変らないか？

（筆者註，鈴木実験に対しての質問）

鈴木(繁)：全部干粉であつた。生粉の状態で貯蔵する のと火力乾燥とでは違うのではないか。吾々は シリカゲルで徐々に乾燥したもので生粉と同様 に考えて良いと思う。

福場: 小麦澱粉で法干粉, 生粉を比較したが差がなか つた。(干粉はフラッシュドライングのもの)

二国：乾燥の際，水分 $25 \%$, 温度 $100^{\circ} \mathrm{C}$ 位传長時間 乾燥するとミセルの再配列が起り, 硬い澱粉に なるから注意する必要がある。フラッシュドラ イングの場合には，殆えど澱粉の性質に変化が ないと思う。

小巻：生粉は膨潤し易いが, 干粉は膨潤し難い。(経験) 田口：ベーキングの際, ビスケットを焼く時ハイドレ
ィションのオーダーにより、かえつて硬くなる。 脂肪が多い程糊化が進まない。又 $\alpha$ 化の少いも のの方が硬くなる。

二国：ビスケットは全部 $\boldsymbol{x}$ 化していると思う。ビスケ ットの硬い軟かいという問題は，澱粉だけでな いのでよくわからない。

田口：ビスケットの $\alpha$ 化したものは $20 \%$ 位であり， 顕微鏡でみると，殆えど複屈折をもつている。 これは二国先生のミセルの再配列が起るという のとよく似ていると思う。

座長：それでは实際問題として磨砕の問題から始めた い。工場の現場に於ては重大なのでこれからや りたい。

山崎：最近径の太い磨砕ロール（径1.3 尺）が各工場 で採用されつつあるが，このロールの得失及び 意見を聞きたい。又これを使用したデータがあ れば知らせてもらいたい。

武井：現在鹿児島では実際にこのロールを使用してい る。然しこの比較試験は磨研した場合にコッパ が出ると比較出来ない。周速度が同じ場合には 径 1.3 尺のカが能力が大きいと思う。詳細なデ 一夕は鹿児島の山村氏のところにある。

桑幡：昨年，一昨年これが問題となつた。別にデータ は持つていないが，経験上長いロールはバラン スがとれ難い。私の考えでは巾は短い方が良い と思う。鹿児島で法徐々に短ロールに变りつつ ある。(現在 $80 \%$ 位が巾 1.3 尺, 径 1.3 尺)更に 短いものでは, 巾 9 寸, 径 1.3 尺 1700 r.p.m 位のもある。能力は 1 時間 $600 \sim 700$ は無理なく 磨砕出来る。所要馬力は $7.5 \mathrm{P}$ である。

座長：いもの入り方, その他の条件によつて処理能力 も変つてくるので, 横の比較法難しい。

福島(三重)：私の使つた経験を伝えると, 径17时 (1.6 尺）内周 5 尺，長さ 2 尺， 1400 r.p.m 1 時間 500 貫のものを 2 年間使つたが，昭和 31 年度磨 砕箱を変えたが失敗に終つた。径が大きくなる と, 吸込角度が問題となる。急にブレーキをか ける状態となり, 馬力を多くくつた。この角度 をなくすることによつて解決した。

座長：メーカーの方に聞きたいが，加滅板の具合等は ぞう学のか？ 長崎の場合, 径 1.3 尺, 長さ 2 尺とし，プーリーで回転数を変えた。回転数を 少なくした場合の澱粉含有率は多く，径を大き くして，円周速度を大きくすると効率が良い。 
二国：昨年長崎へいつた時，大内氏と同行したが，目 立を機械でやる場合，優秀な目立師を各工場で やとつたらどうかという話しがあつたが，これ はどうなるのか？

島田：現在実施中である。

川北(三重)：ローラー及びメタルが大きいと，機械的 な損傷が起るのでこの対策が必要である。

川島(宮崎)：大きな問題(機械的)はロールのバランス の問題である。径が大きくなるにつれてロール のバランスもとりにくくなる。この点はメーカ 一としても気をつけなければならない。

座長：動的バランスはどうか?

川島：バランスマシンを使えば良いが，実際的には不 可能である。実際には各工場にまかせている。 二木(鹿児島)：完全にバランスがとれていても，取付 法によつて狂う場合がある。これについて考案 したものもあるが今は発表出来ない。

福島 (千葉)：経験範囲を述べると従来関東では薄板口 ールが多く使用されていたが（関西では厚板ロ 一ル）原パイプのパイプをひき，外形を仕上げ る。そして細かに目立をするのであるが, 各種テ ストの結果細目のものは能力が落ち面の多いも のは能力を増す。現在 1.25 尺ロールも出ている が 9 寸径のロールが多い。経済面より急速に変 えることは困難だが，徐々に变えるしかないと 思う。現在 1.800 2.000 r.p.m でやつている が,これにはメタルの精密工作が要求され，や つかいなことであつたが，現在では取付に正確 を期している。過去に於てロールのカガミに問 題があつたが(粕が入つてメタルがいたむ)現在 では，ロールのカガミも $0.5 \mathrm{~mm}$ 以上正確で, 回転数も $2.000 \sim 2.500 \mathrm{r} . \mathrm{p} . \mathrm{m}$ 位までは出して も差支えないと考元ている。

剣持(埼玉): 先程の処理能力中 1 時間 600貫というの はロール1本の場合かどうか？

桑幡：1本の場合である。然しこの量を処理したので はロールの目がもたないので，平均 1 時間 350 〜400貫程度処理している。

本坊(鹿児島)：普通の磨砕ロールとハンマークラッシ ャーの得失についてデータがあ机ば教えてもら いたい。

大野：両者は本質的にちがうものであり，比較は出来 ない。現在の磨研ロールの方が良いと思う。又 動力的にみても現在の工場では無理である。
黒川(奈良)：(1奈良県で葛湟粉を作つているが，葛の 根注非常に固い。側板の間があくので，下段に ロールだけでつぶしているが，全体を良くつぶ す機械はないものか？

(2)現在使用している機構では指先が危険であるが （次図参照）この対策はないものか?

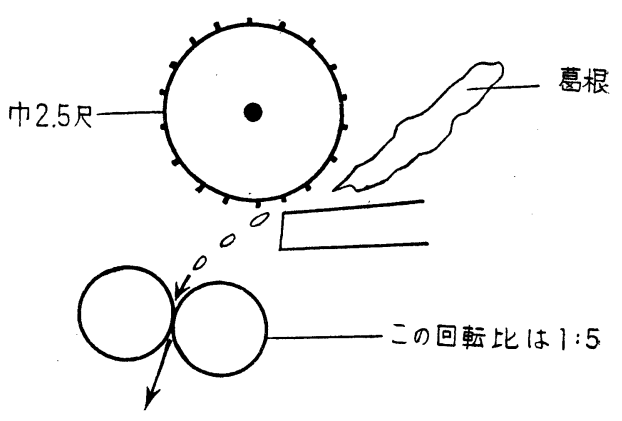

これでも粗い切片が残り能率が悪い。

福岡：実際機械をみていないので，よくわからないが アメリカではバーミルでやつているが，大野氏 はどう思うか。

\section{分 離 機}

石塚：澱粉メーカーの仕上節は JIS の様なものに従つ ているものかどうか伺い度い。

福富：一般には寸目を使つているものが多い。 桑幡：私の所では寸目，时メッシュ両方使つている。 川島：寸目を使つている人が多いと思う。最近羽二重 の網ができてきた。

石塚：仕上げ節は JIS に決まつた節を用いなければな らないのではないか。

山村：金網は縦と横の差が大きく，ビニール，絹網は あまり差がない。ビニールの場合水につけると 膨れてくるが，之と金網と比較しているので， その結果も近く澱粉工業学会誌に発表したいと 思つている。

後藤：良心的な金網メーカーは標準と大体 8 割位まで 良く合う。

山村：N.P は比較的良くできているように思う。

福岡: X 18 が一番細かく, 乾燥状態で 200 メッシュ 位になると思う。

後藤：タイラーでは系の太さ，穴の大きさが決まつて いるが，絹節にはない。

福島：三重県に於ては昨年は一応寸目 120 メッシュで 統一されていた。 


\section{觢込沈澱池}

白井：摺込沈澱池について。 3 巻 3 号に摺込沈澱につ いて表面から 1 尺 5 寸の深さの乳液をとつて沈 降曲線を作つているが，それより深い場合如何， 又沈澱池の深さの限度。

山村：表面から 2 尺の深さの所の液を一定量とり，之 を遠心分離して底に集つた分を $\mathrm{A}$ とる。Aを
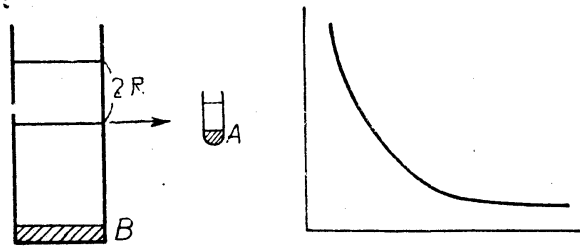

沈降曲線にとる。 $\mathrm{pH}$ をうまく調節すれば沈降 時間を 8 時間より延ばすこともできる。

摺込濃度別に沈澱しない

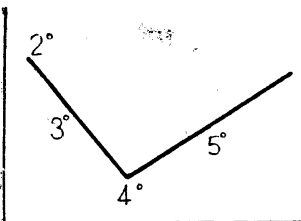

量を測つたこともある。ボ 一メ4度に於て上澄に逃げ る澱粉量が最も少くなり。 その前後で増加している。 小沢：品種別ではどうか。

鷺山：私も同じ様な実験を 農林 2 号, 護国について行つた。摺込乳をスピ ッツ管にとつて遠心分離して行つたが，何れも ポーメ 4 度で限界にきた。

八木：飴をつくつている際に千粉を洗い直している が，それについて同様な沈降曲線をとつたが， 純溉粉に近いものを溶解した場合に，濃度がう すいもの程沈降が早い。

福岡：製品には逃げる分は入つてないからだろう。 八木: シリンダー, ビーカー, 沈澱池等で各々を比較 すると製品については，時間と沈降速度と比例 する。之は澱粉糖技研誌にも発表してある。 長谷：(山村氏に) 時間毎の遊離澱粉も遠心分離されて いるが，とれたものが全部澱粉かどうか？ 山村： 300 メッシュで節い， $0.02 \%$ アルカリで仕上 してあるから全部澱粉として良いと思う。
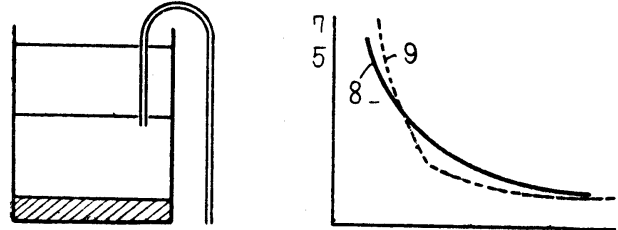

長谷：沈降時間が 8 時間が適当と言われているが，洗 を生じた場合渋がからんで落ちるのか, どうか。 渋がでない場合には浮遊して逃げてゆくと思う が。

山村：醴酵して炭酸ガスを発生すると上水が濁つてく る。整酵してくると澱粉をまき上げるからだろ う。

黒川：葛澱粉でもうすくても濃くても良くない。すて てしまうような褐水をもう一度使うと別れ易い s。

福岡：甘澱では渋をくみ込んで分離をよくすることが ある。之は $\mathrm{pH}$ 低下により澱粉が凝固して別れ 易くなるためではないか。

二国：橴のために $\mathrm{pH}$ が低くなれば粒が少くふくれて 比重が軽くなり，わかれ易くなるのではないか。

山村：酸を入れると沈澱が早くなると言われているが それは反対で，醴酵したものは非常にお抢そくな り，それをアルカリで $\mathrm{pH} 6$ に調節すると，し まりが良くなる。

福岡： $\mathrm{pH} 3 ， 4 ， 5 ， 6 ， 7$ でやつてみたが $\mathrm{pH} 4.5$ 前 後で沈澱が最も早かつた。

山村：酸酵している澱粉乳は $\mathrm{pH}$ を 7 に調節すると沈 澱が早くなる。

大河内：60メッシュ

の節の目では

1 時間半しか

もたないので

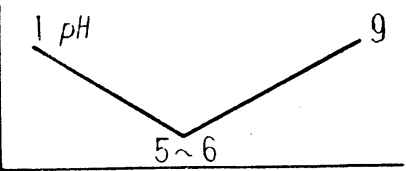

50 メツシニにおとそうと思つているが, 経済的 な節の目の大きさを教えて欲しい。

後藤：磨砕ロールの目の大きさとの関連になると思う が。

桑幡：40メッシュを使つているが，60メッシュではつ

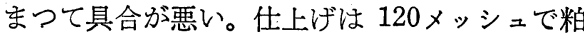
が多い。その後はテーブルでやつているので， ぞこでも粕はとれる。

本坊：穊の目は 60 メッシュで，仕上げは 120 メッシュ である。ロールの最後から $80,60 ， 50$ メッシ ことつけてくるが, 普通は仕上げの 120 メッシ ュまでは 60 メッシュをつかつている。

不明：穊の振動方式について伺い度い。

二木：コロ式が現在一番多く使われている。懸垂式は 力をとらないが，中心を支えるのは難かしい。 大野：理論的にはコロがー番望ましい。懸垂式はつり 方により振動半径が異る。 


\section{テーブリング関係（座長 福岡一三氏）}

福富：これからテーブルを研究しようと思うので，徉 来の甘藷澱粉に使用されているものについて， 巾，公配，長さ等について聞きたい。

桑幡：自分の工場だけについて打答えすると， 長さ 120 尺, 巾 2.6 尺, 勾配 $1 / 400$, コンクリー トモルタル叙りを使用している。これについて は種々の問題があるが, まだ結論は出ない。長 さはどうしても 120 尺は必要と思う。巾以昔か らの 2.6 尺をそのまま使用しているが，今少し セマい方が良い。モルタル仕上げは平面性を保 つのに困難がある。デコボコ面が出来，そこへ 主肉の集積が起る。巾が広すぎると仕上が困難 となる。テーブル上に沈澱した澱粉を運ぶのに は水力を利用しているが，この場合セマい方が 水量動力が少くてすむ。最適の巾は 2 尺程度が 良いと思うが，まだこれは实際に使つたことが ない。これでも澱粉は末端に流亡するので遠沈 器を使用している。

福富：室内と室外の場合のフチの高さはどうか？こ れは風かあった場合問題になると思うが。

桑幡: 室外ではやつたことがない，雨の時困るので高 さは 2 尺位が適当であると思う。

福岡：室内の方が良い。室外だと雨，風の時に困る。 が金の問題で制約を受けるが，最初は屋外に作 り，あとで家をたてることも考えられる。 ノズルゼットを使用する場命, 雨の時にビニ一 ルをかけることも行われている。

福富: テーブル 1 本当りの能力はどの位か？

山村：摺込の場合はボーメ3.0 3.2 (いも 10 貫に対 し水 1 石の割合）で 1 時間 600 貫だと 60 石の 摺込液となるが，テーブル 1 本当り 1 時間 5 石 を流している。

座長：後藤氏のところでは一寸変つたテーブルを使つ ているので，その説明をしてもらいたい。

後藤：最初は折り返しで流す方法を採つていた。

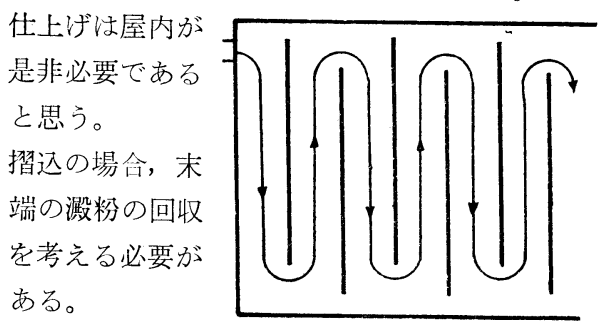

桑幡：四国で行つた仕上循環試験の結果を知らせても
らいたい。

武井：今詳細なデータの持合せがない。

\section{土肉回収}

川島：ボーメ $12^{\circ}$ のものを流している。その処理量は1 時間10石程度で反覆して逐次沈澱させる。実績 は 1.3 万〜 1.4 万貫程度を回収した。1 日に土肉 を 4 時間流している。テールを高メッシュ節に かけてそれを沈澱させる。普通法の 3 倍の能力 が出る。内ノリが2.1尺, 長さ 85 尺, 勾配 $\frac{1}{400}$ である。これを使用すると水量を調節するだけ で, 手間もかからず極めて簡単に土肉より澱粉 が回収出来る。

細淵：現在ボーメ12 度でやつているが，ボーメ14度 にしてロータリースクリューを使うと，テーリ ングポーメ 0.7 度となる。この場合仕込温度が 影響してくるが, $20^{\circ} \mathrm{C}$ 前後が最適である。

大野: 石炭, 砂等の場合に法粉体力学でわかるが, 澱 粉の場合は非常にむら゙かしい。澱粉の場合には 理論よりも経験的なととが多いので，これをも とにしてやつた方が良い。

モルタル仕上げは難しい。プレコートすること によつて澱粉面で平にすることが必要である。 現在流量を多くして土肉を押し流しているが， 適当な濃度, 適当な速度でやるのが一番良い。 白井(神奈川)：摺込の場合 120 尺の長さの時, 実際テ 一ルの処理如何?

若松(鹿児島物産)：経験だけを話すと, 昨年まではテ ールを渋ダメにためていたが，これではあるが 面倒なので, 昨年よりノズルゼットを用いて遠 心分離を行つている。摺込乳テールをノズルゼ ットにかけるのが最も良いが，熟練を要する。 この方法浪質港粉を得るのに現在では最適な 方法であると思う。

二国：テーブルと遠心器との併用がよいのか, 又は遠 心器, オリバーフィルターが良いのか?

座長: 本来㤬心分離器, オリバーフィルターが良い が,金がないのでテーブルを使つているわけだ。

細淵：遠心分離とテーブリングの比較如何？

座長：両者の効果はアメリカの場合, 殆えど同じだ。

細淵：地上澱粉はそうかもわからないが, 地下澱粉の 場合はどうなのか？

座長：日本の場合（特に甘藷）土肉分離が問題となつ てくる。マーコが良いか，ウェストフォリヤが 良いかはここでは申し上げられない。ただコー 
ンスターチの場合, 蛋白の分離にはマーコの方 が成績が良い。遠心器にも各種の型があるが， 夫々の特徴があると思われる。

細淵：金属イオンの増滅汢どうなのか?

座長：水洗については食研の鈴木氏がやつている。

細淵：テーブルで沈澱した澱粉をサンプリングして鉄 をはかつた。澱粉を鉄イオンを含まない純水で 何回洗つても鉄イオンがとれないが。

鈴木(繁)：白玉粉，甘諸澱粉の場合水洗いにより，鉄 が増加している。これは鉄が不溶性となつてい るので当然である。

\section{遠心分離}

蕗山：ノズルゼットに摺込乳をかける時に生ずる泡の 消し方はないか。

武井：ノズルゼットの上にヘッドタンクをおき，次に コントロールタンクをおいて防いでいる。

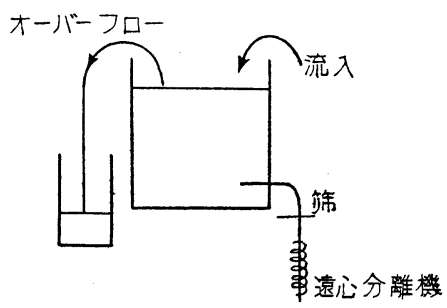

品川機械：小麦澱粉では発泡するが，甘藷澱粉では温 度が $22^{\circ} \mathrm{C}$ 以下では発泡しない。また小麦澱粉 では原液に水を加えて所定の濃度にすると発泡 しない。

武井：乳液が完全に節われていないと発泡し易い。 図南工業：へッドタンクと六イプが問題で，適当なパ イプ,バルブを使用して空気の吸込みを防ぐ様 にする。

福岡：蛋白と樹脂の問題で，うすければ泡がでないの ではないか。

東洋釂造 (近藤)：ト゚ラバルタイプでやつたが，でてき た澱粉がよくしまらなかつた。それは澱粉の濃 度が高いためだと思われる。

八木：小麦澱粉で泡がでるが，原料の影響がある様に 思われる。原料の扊分が増加して $1 \%$ 以上にな ると大部分が泡を生ずる。また特定の品種で, 如何なる濃度にしても発泡せ好ものと，逆に発 泡し易いものとある。しかし発泡現象は蛋白と 灰分の間に相関があり，灰分が増加すると可溶
性蛋白が増加する。発泡現象はそのためではな いか。

後藤：甘藷港粉の場合も今のと似た傾向がある。 昭和産業：ノズルの機質が痛み易いが，将来何か良い ものにする計画ありや。

品川機械：S.S54 を使用している。当然ステンレ スに改めるべきものであるが，今年度以降は別 の材料で内部の磨耗を防ぐようにするつもりで ある。国産のステンレスも良いものがあるので 分離板には使つている。また需要者の要求で希 望の材料を使つている。ノズル口の磨耗はサフ フイアを使うことにより使用期間を延長し得る。 (8 ケ月位)

乾 燥

二国：乾燥について補足する。

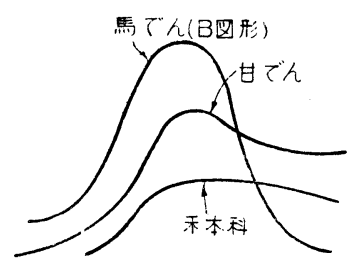

澱粉に熱をかけるとだんだ 几と硬くなる。即ち生馬鈴 薯澱粉（水分 $23 \sim 17 \%$ ）它 $100^{\circ} \mathrm{C}$ 以上 $120^{\circ} \mathrm{C}$ 位まで 加熱すると, 禾本科型の糊 の性質を示すように变つて くる。

細淵：硬いということについて分子構造で説明された い。

二国：分子構造には変化はない。ミセルがむしろ安定 な形となる。大体 $100^{\circ} \mathrm{C} 5$ 時間, $120^{\circ} \mathrm{C} 1$ 時 間位の加熱でこの様な現象を生ずる。また 120 ${ }^{\circ} \mathrm{C}$ に加熱すると, 馬澱は B 固形が A 図形に变 るが $110^{\circ} \mathrm{C}$ では変らない。

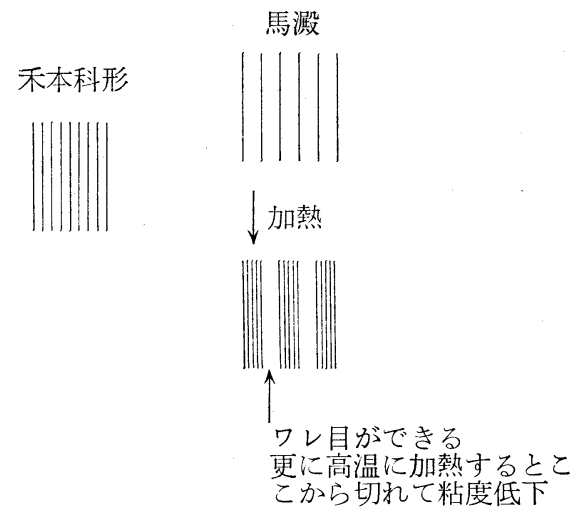

山村：23〜17\%まで乾かす理由は。

二国：23\%以上は $\boldsymbol{x}$ 化してしまうからである。17\% 以下では不変（焦げるまで殆ど不変）。 
福岡：このようなことが乾燥機の設計に問題となつて いると思う。

二国：もつと細かく水分と温度の関連についてやつて みたい。この程度の水分 $(23 \sim 17 \%)$ の場合が いわゆる湿熱変化に相当するのでないか。

山村：水分が $35 \%$ 位の場合, 少量の有機酸がある時 糖化が起るか。

二国：デキストリン化すると思う。

山村：澱粉を脱水機で吸引して45\%位まで水分を除い た時, その表面を叨いていると水がでてくるが, これは澱粉がポーラスで水を吸着しているのが原 因ではないか。

二国：Free water が $17 \%$ 位あると思うが，澱粉を 完全に脱水するとX線図形も变つてくる。

梁田：シールすると固体も温度上昇をする。

鷺山：二等澱粉はミセルが硬いから 糊化が禾本科型 （アミログラムの?）に变ることについて説明 願い度い。又 $100^{\circ} \mathrm{C}$ で無水物にした澱粉の吸 湿試験を行つた時, 二番粉は一番粉より吸湿し 易かつた。

鈴木(繁)：ミセルが硬ければ水が入りにくいからでは ないか, 又澱粉の絶乾物をつくる時, 澱粉の他 に蛋白質の変性という要因も入つてくるのでは ないか。

二国：澱粉の水分定量法の決定的なものはない。澱粉 の場合，それを何分間ではかるかが問題で，一 般の乾燥剂よりも澱粉の方が良い乾燥剤である から，貯蔵中にどんどん水分含量が増加してく る。結晶水は $10 \%$ が限度でそれから先は Free water であろう。

鷺山：デシケータに入れて 15 分間位で秤量している が湿度の関係でどんどえ変つてくる。大体 24 時 間位で $12 \%$ 位になり，それ以後はあまり増加 しない。

二国：馬澱型のものは禾本科型より結晶水が多い。1 モルに水分子 1 ケより多いのではないか，ただ 乙不純物との関係はわからない。

鷕山：一般に甘澱は $16 \%$ \%らいある。

昧の素：関係湿度 $70 \%$ 位で平衡水分。13\%これは乾 燥カープと吸湿カープの両方の結果が $13 \%$ 位 でー致する。

福岡: $13 \%$ \%らだと思う。

菊池：馬鈴著澱粉は吸湿性が強い， 1 年間貯蔵した後 水分を定量すると，18.5～19\%位になつている
ので，他より吸湿性が強いように思われるが。

二国：10\%が結晶水でそれ以上は附着水であるといつ たが，鈴木氏は不純物の面より検討していただ き，私は結晶構造の方より調べたい。

菊池：綿袋の方が紙袋よりも吸湿性が強い， $3 \sim 4$ 月 頃に汲湿して水分が最高になる。

二国：コーンスターチで大体で停つている。

中村：一番粉・二番粉の大きな違いは水分であり，触 感検査では干・生粉何れもあまりちがわない。 二番粉は $2 \%$ 位高いようである。之は二番粉が 粒子の表面積が大きい理由と関係があるように 考える。

小巻：加熱時の再配列に結晶水も加わるのか，フリー ウォーターもか。

二国：結晶水は再配列に関与しない。澱粉の構造中の 鎖のユサブリに関係あるのはフリーウォーター であると思う。

福場：赤星氏が粳・糯について比較したが，糯の方に 結合水が多かつた。之と軟質米，硬質米之関係 があると思う。

二国：生澱粉の場合，アミロヘクチンが結晶に一番関 係する。

菊池：火力乾燥した澱粉は「なき」が悪くなるが，之 は何に起因するか。

鈴木(繁)：今馬澱の品質について検討しているが，そ のなかで，「なき」の問題についても研究して いるが，未だ申し上げる段階ではない。現在は 主として光沢について行つている。

武井：白度計で測定した結果，火力乾燥の方が少し下 まわるようだ。

菊池: 二番粉の水分について説明してほしい。

中村：一番粉の生粉を醴酵させた時，飽和水分が，酸 酵でえ粉とコントロールでは違つて，醴酵でん 粉は $2 \%$ 位多い。カビが生えると粒が犯される が，それらのポーラスな部分と水分との間の関 連如何?

二国：馬澱は表面が割合硬いので，醢酵した場合には 皮を一枚ゔつはぐ椂に犯されるかも知れない。 他の澱粉はカビに犯されてポーラスになること るある。

菅野：昭和 5 年頃やつたのであるが，15尺 $\times 2.5$ 尺 で $120 \mathrm{kcal}$ 熱して上から澱粉を落した乾燥の状態 と,フラッシュドライングの状態と, 北海道の 馬澱の折乾燥の粉の状態と良く似ている。即ち 
ッャがない, 短時間に高熱で乾燥した場合には 各䊀子の表面状態が多少変るのではないか，即 ち目に映る屈折が变るのではないかと思う。ト ラムドライヤーで高温急速にやつたものもツャ が悪い。

近藤：澱粉の白度と吸湿に関連して, 水飴の乾燥をや つていて気がついたが, 水飴を乾燥した時ポー ラスなものには光沢がない。ポーラスなものは 見た目に白く触感も水分を多く感じる。水分は 赤外線含水率計でやり, 比体積も測る。これら の水分, ポーラス, 比体積の間の関連から吸湿 と平衡水分を調べたい。

また澱粉については, 精製澱粉が非常に乾燥 が早く 3 日で $14 \%$ 位になる。(今年は特に乾燥 していた理由にもよるが昨年同期の 7 割位の早 さであつた）この澱粉を綿袋につめて石室に貯 蔵をして，1ケ月後に水分をはかつた所，水分 には全然変化がなかつた。以上両方の関係から ポーラスと不純物が吸湿に影響あるのではない か, 精製した澱粉は平衡水分は $12 \%$ 位になる のではないかと考えている。

後藤：その澱粉の精製法注，

近藤: 澱粉乳 $\mathrm{pH}$ コントロール——洗策—-200メッ シュ一一遠心分離——オリバーフィルター—— 溶解—オリバーフィルター

中村：乾燥方法及びその条件。

近藤： $5 \times 1 \sim 1.5 \mathrm{~cm}$ の大きさの玉。

小巻：水分定量の赤外線照射の時間は?

近藤: $110^{\circ} \mathrm{C} 30$ 分コンスタント。 前田(三重大)：生粉で経験したが 15 分位で乾燥する。 電圧又は赤外線ランプの距離を加隇して, 千葉 前沢氏式に真空にした方が良い。30分は時間が 長すぎるようだ。 $50 \mathrm{~g}$ のサンプルは多くない か。サンプルの厚さ, 分布は均一か。

近藤: 予備乾燥してから温度上昇, 厚さは $7 \mathrm{~mm}, 50$ g のサンプルはクロロホルムの試験をやるので 多いのだ。

黒川：14\%までになる時の気象条件は

近藤：気温 $13^{\circ} \mathrm{C}, \mathrm{RH} 60 \%$, 折枠 10 段（加熱せず） 八木(埼澱化)：ケットで試験したことがあるが，15分 間位で恒量になる。175 ワット 30 分で恒量そ れ以上では僅かに減る。干粉の 15 18％のも のについては $0.2 \%$ 位の差がある。恒温器によ る乾燥\%と，ケットによる\%と差がある。これ
はランプの距離によるのではないかと思う。 中村：水飴をポーラスに乾燥するには?

近藤：スプレードライヤーをつかつて，高温でチャー ジ量を多くすると粒径が大きくなる。

谷川：澱粉の水分をどこにするのが適当か，九州に於 ては風乾で 18〜16\%位にまで乾燥する時があ る。それは大体北風の強い時である。しかし 1 年間に 1 ケ月位 $18 \%$ にはできないで，19〜20 \%位までしか乾かない時がある。フラッシュド ライヤーの乾燥澱粉は, 粉末になるので消費者 が嫌う。水に混入して良く擤捧せねば，溶けな いのでそれの解決に悩むからだ。

鈴木(繁)：以前の論議で水分注大体 $16 \%$ 位が適当と 言われているが，日本の実態では一部の地方で は普通の方法では 18\% にまで行かないととが ある。その地方は 18.5 19 \%にまでして欲し いと言つている。これは実態を考えて決めるべ きだと思う。北海道では水分が規格を僅かには みだす時には，入目を増して解決している。こ れは良い例で，甘澱にもこの様なことを提案し たい。

武井：その年の気象条件によつても随分变る。去年は 悪かつた。

菊池：米の場合に次の様な式がある。即ち水分 $20 \%$ のものが $18 \%$ になた時に $2 \%$ の水分の他に 損失が $\left(100-\frac{100-\beta}{\alpha}\right) \times$ との重量,である。 之を澱粉の場合に適用したが, 生粉を $18 \%$ の 水分までに乾燥する時何\%の歩留りになるか

大野: 乾量基準の水分と湿量基準の水分の 2 通りあ

り, 我々は湿量基準の水分を使用している。

例えば乾燥前水分 $18 \%(\alpha) \mathrm{W}^{\alpha}$ 乾燥後水分 $16 \%$ （ $\beta \%$ W $\mathrm{W}$ とすると $\mathrm{W} \beta=\frac{100-\alpha}{100-\beta} \mathrm{W} \alpha=\frac{82}{84} \mathrm{~W} \alpha \doteqdot 0.97 \mathrm{~W} \alpha$

例 生粉 $45 \%$ —干粉 $18 \%$ にするには

$\mathrm{W} \beta=0.67 \mathrm{~W} \alpha$ となる。

しかし実際に用いられている換算計数は 0.65

であつて，2\%損をしているわけだ。

\section{[第 2 日]}

\section{二番粉の回収（座長 福岡一三氏）}

大河内：昭和 28 年エアレーション（通気処理）を行 つたが，その際気づいた点を述べてみたい。三 立工業の移動㩭抖機を使用して, 渋溜, 沈澱池 にまきついた澱粉の回収を行つた。1日 8 時間 
続けて移動掜找を行い，これをそのままにし， 翌日引続き 4 時間攪找を行い, 計 12 時間攪挥 した。その場合泡が出るので，この泡をとり澱 粉を分離した。

桑幡：攪找液の $\mathrm{pH}$ が影響すると思うがどうか？ 大河内： $\mathrm{pH}$ は 5.0 6.0 で一番良く発泡するようで ある。

川島(茂)：宮崎の場合を話すと, 昭和 30 年度は澱粉 が悪かつたため, 交献をみて摺込量を多くした が，いもの滞貨で摺込澱粉を重衫ることが，行 われた。一昨年は発泡処理を行つて好成績をお さめた。濃度をボーメ 17〜18 度にして, 三立 の移動㩭挷機を使用した。一番粉で 4〜5 時間 行い寄込タンクで発泡させる。二番粉では 10 時 間攪拌すると一等澱粉となつた。又泾処理によ つて得た澱粉は,分離も良好で白度も上昇した。 山村：広島県の三原澱粉工場で実際行つている方法を 紹介寸る。摺込で成功している。

連続式浮かし取機（实用新案申請中）
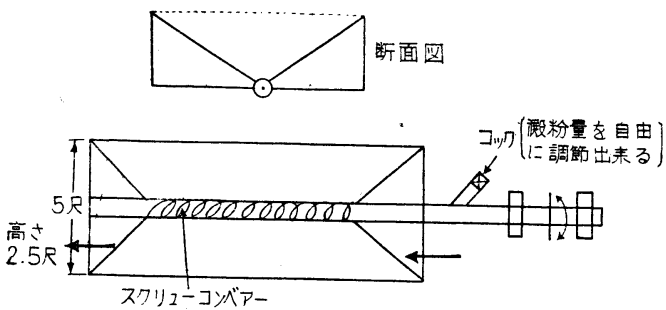

【註】巾 5 尺, 高さ 2.5 尺, 長さ 15 尺, チャージの際の濃度ボーメ 3 度, オーバーフロウ液の濃度ボーメ 0.7

処理量 1 時間当り 45 石

この装置で浮かし取を行うと好結果を得る。

不明：普通流量を 1 時間当り 12 石位にしているが, 上記の場合流量は 2 倍半となる。最近宮崎, 鹿 児島では，節を使わない処理方法が行われてい る。循環式は処理が迅速で結果も良い。

大野：遠心器を使用して，土肉，二番粉を分離してい る工場があるので紹介する。四国の多度津でス キミング型遠心器（無孔壁バスケット型）を使 用して好結柴をおさめている。

径 43 时, 毎分 1100 1150 回転, チャージ澱
粉乳ボーメ $12 \sim 13$ 度, 処理能力 $500 \sim 600$ 貫 8 時間（無水澱粉として） モーター 7.5 馬力

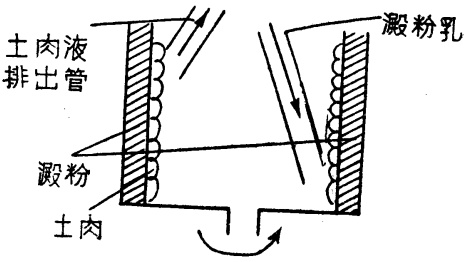

条件によつては，ノズルゼツトを使つても出来 ることが㐫る。それはタンクに溶解し，移動攪 拌機学使用し，これを遠心器（ノズルゼット） にかけ，濃縮液を又元のタンクにもどし，これ を繰返し，ある浱度に達すると完全に土肉を分 離することが出来る。

三重(氏名不明)：二番粉を回収するよりも，二番粉を 少くすることの方が良いと思うが。

座長：これは各工場によつてちがうので，別に標準は ない。

鷺山：摺込の一番粉を沈澱池に移し，これをテーブル にかけ，一番粉をとり，二番粉に相当するテー ルの部分を浮かし取りし，回転節（アンドン 節）にかけ，更にこ杂ノズルゼットにかけて いる, 従つて二番粉のための寄込タンクを必要 としなくなつた。

大河内：二番粉の問題は原料いもにも関倸があると思 引。

座長：二番粉はない方が良いが，多くて悪いと断定す ることも出来ないと思う。

山村：仕上穊と土肉量との関係を調べたデータがある ので報告する。

\begin{tabular}{|c|c|c|c|}
\hline $\begin{array}{l}\text { タイラー } \\
\text { 節目 }\end{array}$ & $18^{\circ} \mathrm{Be}^{\prime}$ & $15^{\circ} \mathrm{Be}^{\prime}$ & \\
\hline 60 & - & 18.99 & \\
\hline 80 & 11.25 & 13.27 & \\
\hline 100 & 12.73 & 13.17 & $(\%)$ \\
\hline 120 & 9.32 & 10.76 & \\
\hline 150 & 9.09 & 8.40 & この篩は他の試 \\
\hline 200 & 6.95 & 6.00 & 験でれ相当使いた \\
\hline 250 & 7.94 & 7.02 & 土肉量が少ない。 \\
\hline 300 & 4.80 & 6.46 & \\
\hline
\end{tabular}

条件： $\mathrm{pH} 4.0,18$ 目/寸 0.7 寸(目の高さ) 品種 農林 2 号, 穊径 1 尺, 


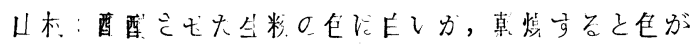
つく, 塩酸で $\mathrm{pH}$ を調節すると, 土肉の量が多 くなる。醴酵すると土肉量が少くなる。 $\mathrm{pH}$ が 3.5 以下になると土肉量が増加する。

細淵：土肉だめで酰酵した場合全澱粉がどの位隇るも のか?

川島：現在宮崎でデータを集めている。大ざつぱなと ころで, 原料を 3 ケ月( 1 亿 月) 貯蔵すると, 澱粉として $0.5 \%$ 減る。

武井: 宮崎工試の日高氏が大丸澱粉で 12 月末〜 3 月 初まで貯藏し,スリコミ, ヨセコミの減少率を 調べている。

座長：品質関係はあとで検討することにする。

\section{石灰法 (座長 桑幡一郎氏)}

郷田：石灰処理澱粉は今迄水飴原料としては嫌われて いたが，今度全国測粉品評会で第 1 位に入賞し たものは石灰法によるものであつて，石灰処理 澱粉の認識を少し改めるべきだと思う。技術が 難しかつたり，後処理にでたら目をしたのでは いけないが，之について討論して欲しい，

後藤：長崎では石灰水を清水に加えて磨砕し， $\mathrm{pH}$ は 6.0 7.0に調節して沈澱させる。その後は殆え ぞ清水処理だけである。石灰水の注入箇所は磨 砕ロールの上か下か，穊の末端か，場所によつ て問題がある。末端の粕の $\mathrm{pH}$ が高いと黄色い 粕で硬くなり，粕溜で山になつて平にならない ので具合が悪い。しかし末端から入れた方が澱 粉の分離は良い。石灰水はコンクリート槽でと かし，その上澄をとるが，宮崎では沪過して， 末端から石灰水を出して連続的に行つている。

鈴木(繁)：磨砕ロールに直接かけるとロールの目がつ まつていけないのでないか。

後藤：時期にもよると思うが，ロールにはかけてない からわからない。

鈴木：芋の種類, 堀取り時期にもよりかけ方に变化は ないのか。

川島：石灰水をロールにかけると鈴木氏の言うとおり であつて，目にヤニがつまつて具合が悪い。私 はトーチランプで目をあぶり，ワイヤーブラッ シでヤニを払い，之により新しい目も古い目も 役に立つ, 大体 24 時間操作が可能である。

桑幡：そのヤニは苛性ソーダで落ちる。

大野：石油でもよく落ちる。

桑幡：あまり厚くヤニがたまると駄目である。新しい
うちに次の図の様にロールをまわしつつ，ャニ

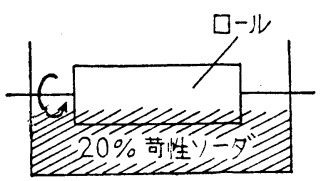
を落す。 山村： $\mathrm{pH} 7$ 付近を普通に 使い, テーブルでは $\mathrm{pH} 8$ 位の所もある。飽和石灰水 の $\mathrm{pH}$ 汇 12.4 12.6 で替込用水の一割位の石 灰水を使う。1 時間当り 50 石の水に対して 5 ～7 石の石灰水を使う。水中に炭酸ガスがある と, $\mathrm{pH}$ はなかなか上らないので, 水中の炭酸 ガス量を測る必要がある。又遠心分離機で石灰 水を振れば, 沪過する必要がない。注水籄所に より $\mathrm{pH}$ が違つてくるが，仕上穊 No1，2，3， …, 7 の順に注入する。摺込部之後の方では違 う。一般に $\mathrm{pH}$ を高くするには，ロール又は仕 上ポンプに入れる。 $\mathrm{pH}$ を高くすると第一期土 肉分難がやり難くなる。 $\mathrm{pH}$ は 7 8 8でが一 番良い。 $\mathrm{pH}$ を 9 9.5 の高いものにすると， 沈降速度も節別效果も悪くなる。穊別効果は摺 込乳の $\mathrm{pH} 7$ が最も良い。

寄込は $\mathrm{pH} 4.0$ で行う。之は蛋白の等電点でも あるわけだが, ボーメ 18 度にする時, 蛋白を 凝固させてやるのが最も良い条件と考元る。pH 7 の方がそれ以上の場合よりも白度が高くでる。 石灰乳を摺込部に入机る場合, ポリフェノール にアミノ酸が働いて緑色に変化する。普通 $\mathrm{pH}$ 7.5 8 で変色する。この色の濃い場合にはポ リフェノールも多い。摺込沈澱池で入れる時は 黑褐色になり，土肉分離は容易である。澱粉の 白度は摺込部で入れた方が高くでる。

長谷：寄込 pHの 4.0 が良いと言うが，そのコントロ ール調節は何でやつているか。

山村：塩酸でコントロールしている。

大河内： pH 4 の製品酸度が高いので, 私は 4.5〜 4.7 でやつている。

山村：洗滌は $\mathrm{pH}$ 4〜5 にもどしてやる。

郷田：石灰法の一般製品の化学分析值は?

鈴木(繁): 石灰法も普通処理も当り前にやつた時の石 灰の量は差がない。

長谷: 石灰法と普通法の澱粉のアミログラフの変化 は?

鈴木(繁)：少し変ると言えるがデータを整理中である ので近く発表する予定である。

不明: 石灰水を作る時, 生石灰と消石灰を使つたが, その優劣を教えて欲しい。生石灰はオリが 1 割 
位でる。

山村：左官用の純白消石灰を使え壮良い。純度（有効 石灰）は普通半分位しかない。飽和度は 0.04 Nである。

不明：大きい攪䢁装置で長時間が良いか。 山村：石灰は徐々に溶けるが,それにも限度があつて，

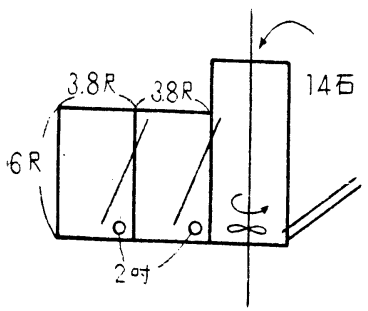

$\mathrm{pH}$ 次第に低くなる。

1 俵/12時間,普通の石

灰は $\mathrm{pH} \mathrm{12.4 \sim 12.6}$

までゆく。化学用では $\mathrm{pH} 13.4$ までゆく。石 灰の溶かし方は上図の 様な装置で行う。

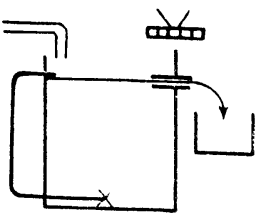

水のチャージ量 5 石,

$5 \sim 7$ 石/ 1 時間,

333 貫の原料に石死 1 貫,

石灰水注入箇所と各ロール

の $\mathrm{pH}$ の変化。

(1) 摺込乳 仕上穊

第 1 第 2

第 3

pH6. 6

6.85

6.85

7.55

8.92

第 4 第 5 不注入

$9.7 \quad 10.15 \quad 10.5$

第 7

\begin{tabular}{|c|c|c|c|c|}
\hline 摺込乳 & 仕上否節 & 第 $\downarrow$ & 第 2 & 第 3 \\
\hline pH9.2 & 9.25 & 9.1 & 8.85 & 8.34 \\
\hline 第 4 & 第 5 & 第 6 & 第 7 & 第 8 \\
\hline 7.95 & 7.8 & 8.0 & 8.0 & 7 \\
\hline
\end{tabular}

この石灰の銘柄は特選消石灰である。

不明：肥料用消石灰はオリが多く，還元しても $\mathrm{pH}$ が あがらない。

山村：消石灰は隔月毎に棄てる。

路山：石死法粕は貨車で送る場合，ガサが多くて不経 済である。

後藤：歩留りは無暗に多くはならないと思う。石灰法. の粕は空気間隙が多くなるので, 輸送は不経済 に思う。石灰水の注入箇所によつても粕の状態 は異り, 磨砕ロールに入れる方が末端で入れる よりも軟かい粕ができる。摺込沈澱池に於ける 上澄液中の澱粉は, 石灰処理しない方が少いよ うに思うので検討願いたい。

\section{水あめ, ぶどう糖関係（座長 鄉田 盤氏）}

座長：本坊氏が不在のため, 酸糖化, 麦芽糖化関係を 一括して討論したい。時閒が制限されているの で両方に共通した問題を一括して討議したい。
関(茨城): 原料澱粉の品質の点で, 高酸度の澱粉が酸 糖化にどんな影響を及ぼすものか？ 許容限界 の 0.5 をこした場合に悪影響があるかどうか？

八木 (埼澱化学)：高酸度それ自体は, 影響しないと 思う。ただ水洗不充分で純度が落ちている場合 は，酸糖化の場合問題となる。

鈴木(繁): 高酸度の澱粉は不純物が多い。酸糖化の場 合にイオン交換樹脂を使用した際, 酸度の高い 澱粉は陰イオンの処理能力が落ちてくるので嫌 われている。

関：若しも影響が少いならば，規格は再検討する必 要があると思う。水あめ，ぶどう糖に適する検 査規準を検討されたい。

不明：食糧新聞に 1 等と 2 等で酸度が 0.25 と 0.5 の 間で, イオン交換の場合 $20 \%$ の差が出ると書 いてあつたが，実際はどうなのか？

本坊：同じ酸度でも製造中の醞酵からくる高酸度は困 る。現在大工場では精製工場をもつているの で，問題とならないが。

座長：麦芽糖化の場合はどうか？

新倉：高酸度は製造中悪臭を放ち, 糖化工程に悪影響 を伴う。

田口（不二）：現在の酸度は\%で表わしてあるが，何 を規準としているのか？

土屋（検査課）：現在の規格は等級別に次のようにな つている。

1 等 $0--0.5,2$ 等 $0.75,3$ 等 1.25

酸度については今後充分検討し, 適切な結果を 出したいと考えている。

測定方法はサンプル $100 \mathrm{~g}$ を $300 \mathrm{cc}$ のフラ スコに入れ， $40^{\circ} \mathrm{C}$ の水 $100 \mathrm{cc}$ を加え振トウ し， 1 時間放置して沪過し，汇液を $10 \mathrm{cc}$ と り, N/50 苛性ソーダで滴定する。この滴定值 を 2 倍して酸度として表わしている。指示薬は フェノールフタレインを用い, ビューレットは $20 \mathrm{cc}$ 目盛のものを使用する。

鈴木（繁）：結局酸度の多い少いは製造過程を丁寧に やつたか否かを表わすものと解釈してよいと思 う。

長谷（神奈川）：精製に関連して, 酸度, 蛋白その他 が考えられるが，利用者側で特にとつてもらい たいものは何か?

座長：これは経営と技術とで見方があると思う。 中村 (鈴木化学)：飴屋としては, 良い物が良いこと 
は勿論であるが，むしろ問題は水分である。ひ ぞい時には，4〜 5\%も多いことがある。これ と臭いである。臭いは水飴工場では再水洗する から良いとしても, 一番粉, 二番粉の問題と関 連して水分が非常に問題となる。水分の点を厳 重に注意してもらいたい。

座長：歩留り, 製品の品質であるが, 酸糖化では最近 イオン交換等の関係でキレイなものを要求して きている。麦芽糖化飴でも昨今は高度なものを 要求されている。水分以外の夾離物についても 問題となる。特に麦芽飴の場合, 夾雑物は細菌 アミラーゼによる液化に悪影響を及ぼし,アク， オリが多く出る。

新倉（植木）：水分は価格の点で問題となるが, 問題 は除蛋白であり，現実的にはこの除蛋白を希望 する。

八木：蛋白に問題がある。これは蛋白が不純物を代表 するという意味からも重要であると思う。

小巻（長頼産業）：酵素の産業的利用という見地から 私見をのべるならば，品質の面で，澱粉粒に水 を加えて放置するとアミラーゼに対し溶けにく くなる。これは今後問題となると思う。原料澱 粉が酵素で $100 \%$ 分解し得るようにすること は，今後の大きな課題である。水溶性不純物は あとまで残るので，これは問題となる。PHを 5.0 以下にすると酵素の処理能力は倍加する。 $5.3 \sim 5.8$ が最適である。又中和の場合, 有機 酸のカルシウム塩が残ると，味を悪くする。石 灰処理測粉は液化しにくいという話がよく持ち 出されるが，この点については今後検 討した い。これは澱粉の本質か，操作かも調べたい。 結晶ぶどう糖の場合も不純物の混入は悪影響を 及ぼす。水溶性化された澱粉だけをとる必要が ある。

座長：種々問題点もあるうと思われるが，時間がない ので，他の機会にゆずり，一応討論を打ち切る ことにする。

\section{経営関係}

座長：問題点を列挙してみると，(1)原料甘藷の問題， (2)製造工程 (3)各項目の経費分布（自然乾澡と 人工乾燥も入る) (4)妥当な潕粉価格となるが 先ゔ(1)ら入りたい。

鈴木（繁）：原料いもの買い方が難しいと聞いている が，後藤氏にその方面のことを聞きたい。
後藤：原料いもの購入はいも業者（仲買人）を通して 買う。長崎県の大村地区は半径 $300 \mathrm{~m}$ 位の間 に，10 工場も固まつているが，いもをどんな ふうに買つたら良いかということが常に問題と なる。いもの水分と澱粉含量の関係を調べ， 1 年間はこれで買つた。これもその年のいもの豊 凶でいくらかちがうが，これでやつている。

澱粉歩留は原料いもに左右されるわけであ るが，会社（業者）の買い方で，昨年泥試合を やつたが，これではいけないので「大村澱粉協 会」を設立し， 約 100 万円で自動秤を購入し て, 共内購入を行つた。これは 9 工場で共同出 資して出来たものであり, 田野澱粉が会長, 谷 川氏が理事長となり運営している。当番は輪番 制である。各工場の内容により，資金が揃つて いない場合もあるので，結果的には金持が各工 場にサービスするようになるが, 田野澱粉の好 意で比較的うまくいつたわけである。購入は原 則として現金払いであるが, 農協で手形払で買 う場合もある。各工場共 1 万 $4 \sim 5$ 千枚の麻袋 を用意して，当番制で回収した。前年は 9 工場 で 750 万貫の予定であつたが，実際には 450 万 貫となつた。これは長崎県が台風でやられ，い もが減産したためでもあるが, 運営面で多少の マサツもあつたが，各工場の協力により大体好 成績をおさめた。全部カンカン（秤量）をする。 初年度として法, 相当の成績をおさめたものと 思う。業者（農協を含まず）の集りだつたので, 農家と多少の溝を生じた。長崎県は切干が多 く，それに迴つたわけであるが，今年度からは， 順調に買付が行われるものと思われる。

福島（三重）：その場合いもの洒格はどうして決める のか?

後藤：それは仲買と農協とによつてちがう。仲買の場 合には 1 俵 300 付ときめ, 運賃は仲買が操作す る。最初は大村着 1 俵 300 円と一率にした。

福島：その 300 円と決定するのはどうして 決めるの か?

後藤：これは協会で決定し, 県の価格となる。

鈴木 (繁)：やつて良かつたか？

後藤：よかつたと思う。

蕗山：共同集荷の場合，原料割当はどうしているの か?

後藤：最初は工場の資金内容をはつきりしてもらい， 
希望数量を出してもらう(前金, 約 200 万), こ の時協定違反をした場合は，契約書を出してあ るので，罰則が適用されるので違反する者はい ない。例えば全量で 500 万貫処理する場合, 100 万貫 (希望数量) を逐次配分してゅく。こ れはトラック一車位に割当てる。

鷺山：その場命等級別区分はしているのか？

後藤：一切していない。

福島：原料いもの選択は？

後藤：一切行わない。

関：農協之仲買の比率如何?

後藤：農協 $30 \%$, 仲買 70\%である。

座長: 愛媛県の場合, 従来原料いもの価格をつり上げ て苦しんだが，経済連の勢力が強いので，県内 だけは各工場別に割当を行つている。いもの価 格は経済連と相談してきめた。

座長：いもの品質, 歩留りについて何かあつたら。

鹭山：泉地区では新盆 (8月 15 , 日頃) に第一回分析 を行う。製造前（9月 10 日頃）に第二回分析 を行うと，大体あとの見当もつく。データは郡 部の天候等は同一と考えると正確にはいかない が，1\%位のフレで自分の工場の予想歩留りも わかり，実歩留りもわかる。新盆の頃の澱粉含 有率注生育途上であるが，8月 15 日頃から 9 月 15 日にかけて澱粉価が充実してくる。分析 法以農芸化学分析書による。曻お可溶性糖と澱 粉との間には相関々係が認められる。

山崎: 広島県で 11 月中旬頃の芋を 140 点分析したが, 中国 5 号が悪いので県に話したところ，翌年よ りこの品種の防止ができた。

後藤：簡易歩留り試験法どうする。

武井：小型磨砕機，ミキサー，毎日の摺込量からみる。 鈴木（繁）：千葉農試で硬度の測定により歩留りをみ た。リンゴの熟度をみる硬度計で之を甘藷に適 用した。之はデータにフレ(芋の部位, 年度等) があるが大ざつぱ尔分類には使える。一般に切 干歩留りが高ければ澱粉含量も高い。

福岡：馬鈴著のように比重法ではでないか。

尾崎: 日本農研の岩崎氏が一応まとめたが, 実用的で はない。

鈴木（繁）：繁村氏が朝鮮に於て比重法についての試 験を行つている。私が甘諸の生育中の変化を研 究した際に，芋の容積重（見かけの比重）を測 つてゆくと，8月 15 日頃を境に变化が現われ
てくる。これは芋の内部に大きな変化が起つて いるからであろう。この変化は大体澱粉含量の 変化と平行した。これは繁村氏の報告の裏付と もなる。

山村：同様なことをやつたが逆にでることがある。農 林 7 号は比重が高くでる。甘藷は馬鈴薯と違つ て空気が入つていることがあるので，これを追 い出すようにしてピクノメーターで（磨砕した ものを）測ると良く合う。

武井：以前㟧品種間の価格差をつけていたけれども， 澱粉工場は現在この椂なことをやつているか。

川島：原料芋の貯蔵堆積中に於ける澱粉の減耗につい て報告したい。宮崎県では短期間に処理するこ とが問題になつている。今迄は集荷が集中する ために，堆積により歩留りが低下した。そこで 昨年度は滞貨なしにしたので, 歩留りも向上し た。勝目農協は原料管理もよく, 歩留りも良かつ た。バラ積みの歩留り試験 (手摺り)の結果は,

農林 2 号で原料芋 26.5 貫が 21.5 貫に減耗 し, 澱粉量も 6 貫から 5.4 貫に減つた。 農林 9 号では原料芋 21.5 貫が 16.4 貫に減 耗し，澱粉量も 6 貫から 5.2 貫に隇つた。 ただし、これは 12 月以降の芋であつたため かも知れないが，とに角バラ積み将いけないこ とがわかつた。

袋積みのまま計量投入が良い成積をしめして いる。

後藤：昨年は 11 月 15 日〜 12 月 5 日の間に急激に 变化している。

鷺山：そんなに変化していないようだが。

鈴木（繁）：自分のデータでは，完熟期をすぎた芋や 降霜後の芋は, ミキサー試験では澱粉歩留りは 正確に出ない。

後藤：川島氏のデータは降霜後の芋ではアミラーゼに 変化が起るので健全芋とは思光ないが。 $5 \%$ の 減耗というのは, そういう原料をつかつたから ではないか。

鷺山：私のやつたデータでは, 108 貫が 103 貫に減つ たが，澱粉洒としては $5 \%$ まではさがらない。

武井・服部：アルコール工場の場合は $5 \%$ 減を認めて いる。

鈴木（繁）：最近は微気像状態に関する研究が盛に行 われている。芋を堆積した際の, 芋と芋の間の 温湿度等の微気象の測定が重要であろう。 
山村：温度 $14^{\circ} \mathrm{C}$ を境にして芋の代謝が旺盛になる。

後藤：甘藷堆積初期は $20^{\circ} \mathrm{C}$ まで上昇するが， 1 週間 後には $14^{\circ} \mathrm{C}$ までさがる。

福島：三重県では堀取を延ばす傾向がある。これは歩 留りを低下させるのではないか？

蕗山：蔓をつけたまま畑におくのは，澱粉の減少率が 大きいためで，つるを㺫り取つて芋だけを土中 にたおと，堀取つて地上にさらしておくよりも 澱粉の減少率が少い。

鈴木 (繁)：1918 年にハッセルブリングが芋の生育 中の成分変化について発表しているが，霜にあ てると糖化がふえるといつている。

山村：昨年 (31年) 注 1 1.5\%平均澱粉含有量が低 い。この原因は何と考えるのか？

福島：自分の工場の経験では, 10月初めまでは前年と 大差がなかつた。10月中旬〜12月一杯にかけて， 歩留りが格段に悪かつた。原因は不明である。

福岡： 8 月 24 日までは旱天続きで, 地上部が枯死し そうになつた。 8 月 24 日にはじめて雨が降つ た。11 月 17 日からは 3 日に 1 度づつ雨が降つ ていた。

蕗山：自分の工場では別に変らなかつた。鹿児島に傍 系の 6 工場があるが，そこでも歩留りに変化は なかつた。原因としては生育初期に旱天が続い たためと思う。分析をする際に賽の目にきる が, 非常に固かつた。その後一旦葉が枯れて, 先端の葉が盛り返したので, 後期は茎葉の繁茂 に使われたので注ないかと思う。即ち葉が何時 までも青々と繁つていた。

座長：愛媛県でも 1.5〜2％歩留りが低かつた。原因 は旱バッだと思われる。

蕗山：いもの水分が少ない。

山村：鹿児島県には線虫が慢延している。

福岡：いもの滞貨と処理の点について聞きたい。

山村：摺込澱粉につき, 現在実験を継続中である。 $\mathrm{PH}$ が低い方が貯蔵条件としては良い。

関：歩留向上のフォクターは原料いもにあるが, 検 査規格の点で歩留りと関連して, 品種により 3 〜 4 階級に分類した方が良いと思うが。

座長：いもの検査規格沙条令で出来る。鹿児島, 宮 崎等でやつている。ただ県によつて採りあげる ところと，採りあげない県がある。

不明：同一品種でいもの大小によつて澱粉歩留りにど のような差があるか?

座長：それは山村氏がやつている。
後藤：余り大きないもは処理上困る。

島田：等級査定は必要であるが, 簡易検定法が完成し ていない。北海道ではどうしているのか？

菊地：北海道ではライマン比重計を用いて，簡単に澱 粉含量を測定して，等級を決めている。7 多以 上で澱粉 $15 \%$ 以上が 1 等, $13 \%$ 以上が 2 等, $11 \%$ 以が 3 等となつている。

島田：甘藷の簡易検定法（器）を考案したらどうか。 この研究費用は業界で出せば良い。学会として も考えてもらいたい。濃度計, 或は比重法等が 考えられる。

会長：何とかして解決したい。

細淵：測定問題について。菏性ソーダに澱粉を浸ける と膨れてくるが，その程度により澱粉量がわか らないだろうか。

鈴木（繁）：澱粉の加工賃の問題について討論してほ 乙W。

坂井：港粉価格は芋の価格が決まつてから決まるが， その他は種々の要素の重つたものからでてくる。 昨年より 30 円位值上げしてある。（基準価格 1,560円)

武井：原価計算は 29 年度集計結果は各澱粉工場でフ レがあり, 生粉の出荷量, 金利の関係, 労務賃 がマチマチでなかなか解らない。

本坊：加工費は 370 600 円位の間だ，その内訳は大 部分が人件費と原料費である。澱粉步留りは最 高最低で $5 \%$ 位の差がある。

武井：乾燥製品と生の製品の量を抑えれば技術的なも のかどうかはわかる。動力費・人件費は大きい が割合にはつきりしている。

本坊：動力を沢山使えばむしろ加工賃が高くつく。

鈴木（繁）：久保田氏の調査によると，九州地方は人 手がかかり，関東地方はあまり人手がかかつて いない。

武井：人件費と動力費注䌂めた方が妥当である。

福岡：タイプが分けられるのではないか。標準工場の 加工賃を調査する必要があるのではないか。

難波：原料貫数で加工賃をみる方が良い。製品では歩 留りが違うので比較にならない。標準加工賃を 算出して，各種タイプを分けた方が良い。

福岡：現場の定員の標準作業の研究する必要がある。 之は人件費と大きな関係がある。

坂井：タイプについて

50 万貫工場の費用 $\}$ 等の各種タイプがある 30 万 " と思う。 
これからの澱粉工場の行き方として, ぞうして も中間経費の圧縮をしてかからねばならない。 妥当な価格で澱粉を売り, 妥当な価格で芋を買 うようにするべきである。

関：最近の原価計算要素として, 粕の問題があると 思う。九州では脱水機等を使つているか。

坂井：粕は農家に還元している。

山村：粕溜ごと売つている。粕は 1 貫最低 1 円 20 銭 最高 3 円である。

桑幡：養豚の多い地方では生ではける。そうでない地 方は処理に困つている。原則としては乾かして アルコール工場に売つている。

服部：アルコール工場は最近新しい分野に進久つつあ るが，澱粉価は 55〜38％のものを， 1 貫 60 円位で買つている。しかし乾燥粕は最近は配合 飼料に売れている。

\section{化工澱粉・小麦澱粉（座長 菅野敏氏）}

後藤：長崎では石灰法澱粉は晒澱粉にすると粘度が低 く，カマボコ屋は石灰法澱粉を嫌う。これらに ついて説明を願いたい。

菅野：悪いものを使うためか。

不明：石灰法港粉は唒しても白度があがらない。

本坊：石灰法搌粉は唒にした場合嫌われる。ハルサメ
の原料にも適さない。しかし一番粉の哂溉衯で はクレームはない。二番粉・石灰処理澱粉・貯 藏澱粉（生粉だめ）で作る唒澱粉はどうも具合 が悪い。

菅野：カルキは何で中和したか。

不明：硫酸をつかう。

菅野：硫酸石灰のためだろう。コシの弱いのは抯し粉 の効きすぎではないか。塩酸を入れて塩素ガス を発生させて，一日おいてから洗滌する所と， アルカリで中和する所とあり，唒し粉の使用量 に欠陌があるのではないか。

後藤：操作に変りはないのに，でてきた澱粉に変りが あるので，疑問を生じているのである。

菅野：個性の違う澱粉に同一操作をするからだと思 う。

鈴木（繁）：同一芋を石灰処理及び普通処理して，そ れらの酔したものと, 唒さないものと比較すれ ば良否がわかると思う。現在私のところで澱粉 の粘度について研究しているので, その一環に とりあげて見たい。

菅野：澱粉共進会に出品した唒澱粉は色づきの多いの があつたが，これは薬品がまだ残つている証拠 である。

\section{本 会 記 事}

理 事 会

（1） 日 時 昭和 32 年 10 月 29 日 午後 2 時

（2）場 所 全販連会議室

（3）出席者 尾崎, 管野, 福岡, 坂井, 久保田, 郷田, 鈴木(繁)，鈴木(芳)，頼富，中村

(4) 経 過

（イ）本事業年度も半年経過したので，鈴木常任理 事より, 会員の現況と6 ケ月間の収支について報告が 行われた。

（口）常任理事の選出莸行い，支部推薦役員は全部 そろつてから，改めて協議することとした。

（八）明年度総会と技術研究会の日程を 33 年 4 月 21 （月） 22 日（火）と決定した。4 月17日から19日まで第 2 回全国澱粉共進会が行われるので，それに引きつづ いて学会の総会を行つた方が地方の会員の為に便宜な ので前記のようにきめたが，澱粉共進会と密接に連絡 することを申し合せた。

（二）明年度の技術研究会に，何等かの形で製造機 械・装置についての研究会を行うよう要望があつた。

（ホ）学会誌の編輯方針について討議して，大体の 会員も異議がないようなので，しばらく現在の方針で 進めることになつた。

\section{新会员名簿}

（昭和 32 年 5 月 27 日〜 9 月 10 日）

特 別 会

北海道経済農業協同組合連合会

札幌市北 4 条西 1 丁目 1 番地

大日本製糖株式会社工務部

東京都千代田区丸の内 1 の新丸の内ビル
東京都千代田区神田鎌倉町 5

横浜精糖株式会社製造課

神奈川県横浜市西区平沼町 1 の 1

\section{涮粉 工業 学会誌}

\section{第 5 巻 第 1 号 禁転載}

昭和 32 年 11 月 10 日 印刷発行

東京都江東区深川浜園町 2

編集兼

発行者

印刷所帝都第一印刷株式会社 東京都新宿区山吹町 305 番地

印刷者

石 井完 一 東京都新宿区山吹町 305 番地

東京都江東区深川浜園町 2

発行所農林省食糧研究所内

澱粉工業学会 昭和産業株式会社 